\title{
Timing and magnitude of equatorial Atlantic surface warming during the last glacial bipolar oscillation
}

\author{
S. Weldeab \\ Department of Earth Science, University of California, Santa Barbara, USA \\ Correspondence to: S. Weldeab (weldeab@geol.ucsb.edu) \\ Received: 19 April 2012 - Published in Clim. Past Discuss.: 21 May 2012 \\ Revised: 21 September 2012 - Accepted: 2 October 2012 - Published: 26 October 2012
}

\begin{abstract}
The timing and magnitude of millennial-scale thermal oscillation in the equatorial Atlantic during the last glacial and marine isotope stage 3 have been perceived as merely a response to meltwater-induced perturbations of the northern high latitude climate. The relatively asymmetric distribution of available temperature records has so far impeded testing whether this view is valid across the equatorial Atlantic. This study presents a centennially resolved record of $\mathrm{Mg} / \mathrm{Ca}$-derived sea surface temperature (SST) estimates from the eastern equatorial Atlantic (EEA) and a core top-based proxy validation. Multivariate analysis of the EEA core top data indicates that the $\mathrm{Mg} / \mathrm{Ca}$ ratio varies by $8 \pm 2 \%$ per unit SST $\left({ }^{\circ} \mathrm{C}\right)$ and $1 \pm 0.9 \%$ per unit salinity (psu) change, indicating that temperature is the most dominant factor controlling planktonic foraminiferal $\mathrm{Mg} / \mathrm{Ca}$ variation. The EEA SST time series exhibits a close correlation between episodes of rapid equatorial surface water warming, the onset of massive meltwater inputs into the North Atlantic (Heinrich events H3-H6), and Antarctic climate changes, indicating that the EEA was very sensitive to millennial-scale bipolar oscillations. Rapid EEA SST rise between $0.8^{\circ} \mathrm{C}$ and $2{ }^{\circ} \mathrm{C}$, synchronous with the onset of Heinrich events, is consistent with the concept of tropical Atlantic warming in response to meltwater-induced perturbation of Atlantic meridional ocean circulation (AMOC). At variance with model results that suggest a basin-wide SST rise during and rapid surface cooling concomitant with the termination of Heinrich events, this study indicates persistently elevated EEA SST during and up to $2300 \mathrm{yr}$ after the abrupt termination of Heinrich events. This study emphasizes that changes in windinduced low-latitude zonal surface currents were crucial in shaping the spatial heterogeneity and duration of equatorial Atlantic surface water warmth.
\end{abstract}

\section{Introduction}

The climate of the last glacial and marine isotope stage 3 was marked by millennial-scale oscillation. Greenland ice cores and sediment sequences from the northern high and mid-latitudes provide evidence of ice sheet instabilities and associated meltwater influxes into the North Atlantic, known as Dansgaard-Oeschger (DO) and Heinrich (H) events (Bond et al., 1997; Blunier and Brook, 2001; Dansgaard et al., 1993; Heinrich, 1988; Johnsen, 1992; NGRIP-members, 2004; Rashid et al., 2003; Vidal et al., 1997). During the Heinrich events, North Atlantic and Northern Hemisphere midlatitude surface water cooled by several ${ }^{\circ} \mathrm{C}$ (Bard, 2000; Bond et al., 1997; Cacho et al., 1999; Martrat et al., 2004; Patton et al., 2011; Hodell et al., 2010). Consistent with the concept of bipolar oscillation (Knutti et al., 2004; Stocker, 1998; Toggweiler and Lea, 2011; Timmermann et al., 2005), southern high latitude marine and Antarctic ice core records indicate surface water and air warming, southward retreat of sea ice, and intensification of deep water upwelling during times of northern high latitude cooling (Anderson et al., 2009; Barker et al., 2009; Blunier and Brook, 2001; Kanfoush et al., 2000; Sachs and Anderson, 2005). Global sea level fluctuation (Siddall et al., 2003) and changes in benthic foraminiferal $\delta^{18} \mathrm{O}$ composition (Shackleton et al., 2000) follow the pace of Antarctic climate changes that is more gradual relative to the abrupt onset and termination of Heinrich events of the northern high latitude. In contrast to the relatively detailed and numerous climate records from both southern and northern high latitudes, the spatiotemporal coverage of climate records in the tropical ocean is fragmentary. 
Much of our current understanding of the tropical Atlantic response to meltwater influx into the North Atlantic is largely derived from proxy- and model-based records of the Younger Dryas (YD) and Heinrich 1 (H1) event (Chang et al., 2008; Chiang et al., 2003, 2008; Krebs and Timmermann, 2007; Lee et al., 2011; Liu et al., 2009; Lohmann, 2003; Hüls and Zahn, 2000; Jaeschke et al., 2007; Lea et al., 2003; Nürnberg et al., 2008; Rühlemann et al., 1999; Weldeab et al., 2006, 2007a; Zhao et al., 1995; Schmidt and Lynch-Stieglitz, 2011; Schmidt et al., 2004; Clark et al., 2012). Warming of western tropical Atlantic surface water during the YD and $\mathrm{H} 1$ events and the ensuing rapid temperature changes (Rühlemann et al., 1999; Weldeab et al., 2006) occurred, however, against the backdrop of rising atmospheric $\mathrm{CO}_{2}$ (Monnin et al., 2001). Consequently, it is impossible to isolate the contribution of meltwater-induced AMOC perturbation to the tropical Atlantic SST rise from contributions related to an increase of atmospheric greenhouse gases (Lea et al., 2000; Shakun et al., 2012). During Heinrich events H2-H6 with atmospheric $\mathrm{CO}_{2}$ changes less than $20 \mathrm{ppm}$ (Ahn and Brook, 2008), SST reconstruction from western equatorial Atlantic suggests SST drops of up to $1.5^{\circ} \mathrm{C}$ (Jaeschke et al., 2007). Testing whether this pattern of thermal response is ubiquitous across the equatorial Atlantic has not been possible due to a lack of highly resolved and continuous records. This study presents a centennially resolved EEA SST record over the period between 75000 and $25000 \mathrm{yr} \mathrm{BP}$, providing new insights into the timing and pace of EEA thermal changes and zonal patterns across the equatorial Atlantic during the onset and termination of the last glacial Heinrich events.

\section{Oceanographic setting}

The focus of this study is marine sediment sequence MD032707 that was recovered from the eastern Gulf of Guinea $\left(02^{\circ} 30.11^{\prime} \mathrm{N}, 09^{\circ} 23.68^{\prime} \mathrm{E}, 1295 \mathrm{~m}\right)$ and core top sediments collected across the Gulf of Guinea (Figs. 1 and 2). In the Gulf of Guinea, seasonal variation of SST is associated with changes in the strength of the Guinea Current (Jouanno et al., 2011a). In the summer (July-September), a relatively strong current corresponds to relatively high sea surface salinity (SSS) of 32.2 practical salinity unit (psu) and low SST of $26.1{ }^{\circ} \mathrm{C}$ (zonal average) (Antonov et al., 2010; Locarnini et al., 2010). Relatively low SST and elevated SSS during the summer are associated with shoaling of subsurface water to $10-40 \mathrm{~m}$ below the surface due to velocity shear caused by the strengthened Guinea Current (Grodsky et al., 2008; Jouanno et al., 2011a, b). During the winter (January-March), relatively warm surface water $\left(28.9^{\circ} \mathrm{C}\right)$ and low SSS (29 psu) (Antonov et al., 2010) prevail due to a weak current (Jouanno et al., 2011a). In the eastern Gulf of Guinea, SSS is strongly controlled by the large volume of runoff $\left(\sim 280 \mathrm{~km}^{3} \mathrm{yr}^{-1}\right.$ ) (www.fao.org) from river systems that drain a large portion of the West African monsoon area.
The proximity of the MD03-2707 core site to the mouths of large river systems results in a high accumulation rate of terrigenous sediment and thus highly resolved time series. The presence of (aragonitic) pteropods throughout the investigated core section indicates that the bottom water was saturated with respect to carbonate ion concentration.

\section{Methods}

The core top samples were retrieved from the Gulf of Guinea across SSS and SST gradients (Lutze et al., 1988) (Fig. 2). Mean annual SST and SSS above the core top sites vary between $26.3^{\circ} \mathrm{C}$ and $28^{\circ} \mathrm{C}$ and between $29.6 \mathrm{psu}$ and $35.4 \mathrm{psu}$, respectively (Antonov et al., 2010; Locarnini et al., 2010). The water depth of the core top samples ranged from $175 \mathrm{~m}$ to $4449 \mathrm{~m}$, corresponding to carbonate ion concentrations (expressed as $\Delta \mathrm{CO}_{3}^{2-}=\mathrm{CO}_{3}^{2-}$ in situ $-\mathrm{CO}_{3}^{2-}$ saturation) between 93.9 and $-0.97 \mu \mathrm{mol} \mathrm{kg}{ }^{-1}$.

$\Delta \mathrm{CO}_{3}^{2-}$ values were calculated from the data set compiled by Key et al. (2004) using a software developed by Robbins et al. (2010). Of the 59 core top samples, 58 were recovered from sea floor that is bathed by bottom water saturated with carbonate ion.

$\mathrm{Mg} / \mathrm{Ca}$ data were analyzed in tests $(250-300 \mu \mathrm{m})$ of Globigerinoides ruber pink (sensu stricto) (Steinke et al., 2005; Wang, 2000). Approximately 25-30 G. ruber pink individuals were selected from core top and down core samples, gently crushed, and cleaned using the oxidative and reductive standard foraminifera cleaning procedure in order to remove contaminants including coating phases (Martin and Lea, 2002). The dissolved samples were analyzed using the isotope dilution/internal standard method in a Thermo Finnigan Element2 sector field ICP-MS (Martin and Lea, 2002). Analytical reproducibility of $\mathrm{Mg} / \mathrm{Ca}$ was estimated at $0.7 \%\left( \pm 0.014 \mathrm{Mg} / \mathrm{Ca} \mathrm{mmol}^{-1} \mathrm{~mol}^{-1}\right)$ based on analysis of consistency standards matched in concentration to the dissolved foraminifera solutions and analyzed over the course of the study. The pooled standard deviation $(1 \sigma)$ of replicate core top sample analyses was $0.06 \mathrm{mmol} \mathrm{mol}^{-1}$. The higher sample standard deviation relative to the consistency standard is most likely due to sample heterogeneity. $\mathrm{Al} / \mathrm{Ca}, \mathrm{Fe} / \mathrm{Ca}$, and $\mathrm{Mn} / \mathrm{Ca}$ and other trace elements were also simultaneously analyzed in order to assess the efficacy of the cleaning process and to detect possible diagenetic influences. Only 12 of 570 samples exhibited $\mathrm{Al} / \mathrm{Ca}$ greater than $80 \mu \mathrm{mol} \mathrm{mol}^{-1}$, indicating that detrital material was successfully removed and that contributions of $\mathrm{Mg}$ from silicate phases to the analyzed $\mathrm{Mg} / \mathrm{Ca}$ are negligibly low (Barker et al., 2003; Lea et al., 2005). $\mathrm{Fe} / \mathrm{Ca}$ and $\mathrm{Mn} / \mathrm{Ca}$ were slightly elevated, generally ranging between 100 and $300 \mu \mathrm{mol} \mathrm{mol}^{-1}$. However, the correlation between $\mathrm{Fe} / \mathrm{Ca}$ and $\mathrm{Mg} / \mathrm{Ca}\left(r^{2}=0.003\right)$ and $\mathrm{Mn} / \mathrm{Ca}$ and $\mathrm{Mg} / \mathrm{Ca}\left(r^{2}=0.1\right)$ was insignificant. The $\mathrm{Mg} / \mathrm{Ca}$ time series was converted into SST estimates using the global calibration equation 


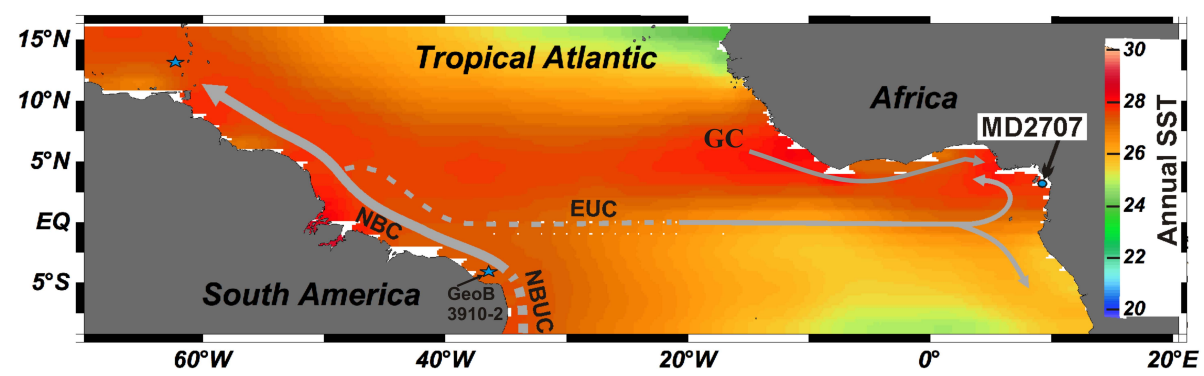

Fig. 1. MD03-2707 core location (blue dot) and annual SST in the tropical Atlantic (Locarnini et al., 2010). Solid and dashed lines indicate a highly simplified schematic of surface current (GC: Guinea Current; NBC: North Brazil Current) and subsurface current (EUC: Equatorial Undercurrent; NBUC: North Brazil Undercurrent) (Schott et al., 2002). Blue stars in the Caribbean Sea (Hüls and Zahn, 2000) and western equatorial Atlantic (Jaeschke et al., 2007) indicate core locations discussed in the main text.
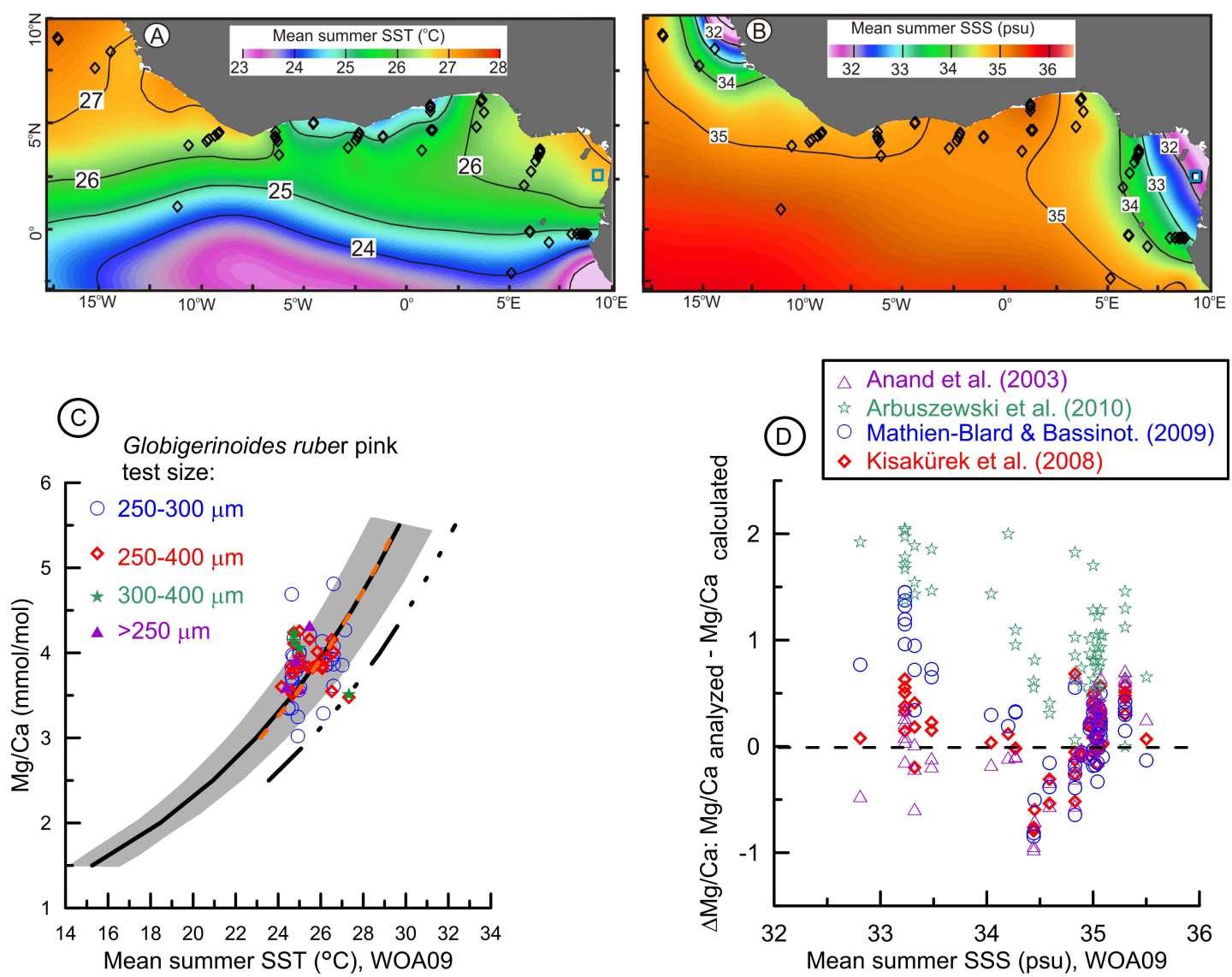

Fig. 2. Mean summer SST (a) and SSS (b) in the Gulf of Guinea (Locarnini et al., 2010; Antonov et al., 2010) plotted using Ocean Data View (Schlitzer, 2012). Black diamonds and a blue square indicate locations of core top sampling and MD03-2707, respectively. (c) $\mathrm{Mg} / \mathrm{Ca}$ analyzed in G. ruber (pink) from core top samples plotted versus mean summer SST (Locarnini et al., 2010). Solid line $(\mathrm{Mg} / \mathrm{Ca}=0.38 \times \exp (0.09 \times T))$ and grey area indicate the global calibration curve and its area of uncertainty, respectively (Anand et al., 2003; Dekens et al., 2002). Orange $(\mathrm{Mg} / \mathrm{Ca}=0.34 \times \exp (0.09 \times T))$ and black $(\mathrm{Mg} / \mathrm{Ca}=0.30 \times \exp (0.089 \times T))$ dashed lines indicate calibration curves for G. ruber white established by McConnel and Thunnell (2005) and Lea et al. (2000), respectively. (d) Difference in Mg/Ca $(\Delta \mathrm{Mg} / \mathrm{Ca}$ ) between analyzed core top and calculated values plotted versus mean summer SSS (Antonov et al., 2010). Calculated Mg/Ca values are obtained using Mg/Ca-SST-SSS (Arbuszewski et al., 2010; Kisakürek et al., 2008; Mathien-Blard and Bassinot, 2009) and Mg/C-SST equations (Anand et al., 2003). 


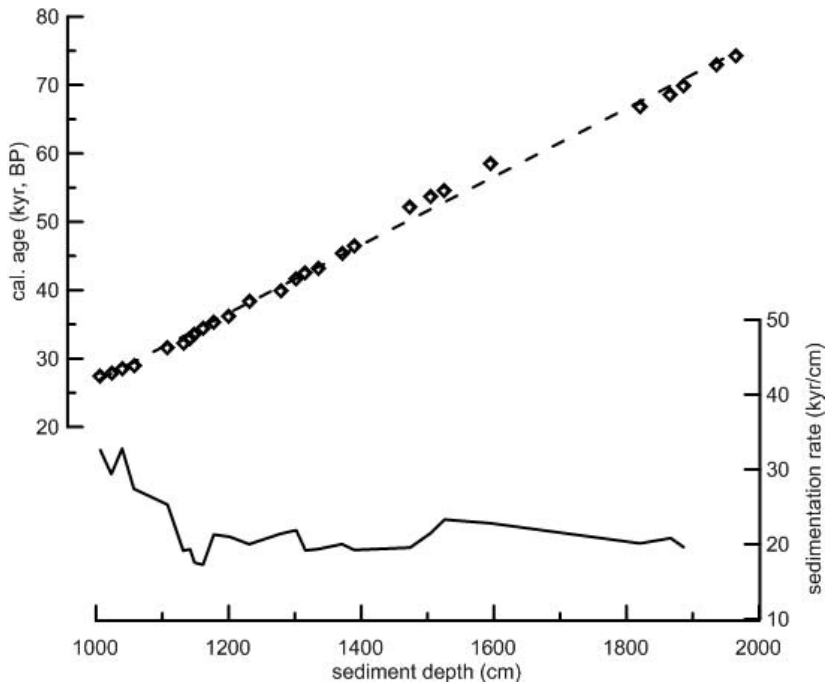

Fig. 3. Ages of tie points (diamonds) plotted versus sediment depth, as obtained by tuning $\delta^{18} \mathrm{O}_{G \text {. ruber }}$ record in MD2707 (Weldeab, 2012; Weldeab et al., 2007a) versus $\delta^{18} \mathrm{O}_{\text {ice }}$ GIPS2 record (Blunier and Brook, 2001). Shown is also a 5-point running average of sedimentation rate plotted versus sediment depth.

$\left(\mathrm{Mg} / \mathrm{Ca}\left[\mathrm{mmol} \mathrm{mol}^{-1}\right]=0.38 \times \exp \left(0.090 \times T\left[{ }^{\circ} \mathrm{C}\right]\right)\right.$ (Anand et al., 2003; Dekens et al., 2002).

I also analyzed $\delta^{18} \mathrm{O}$ in tests of $G$. ruber pink (250$300 \mu \mathrm{m}$ ) from 29 core top samples (Fig. S1) using a Thermo MAT 253 mass spectrometer located at the author's stable isotope lab (UCSB). The mass spectrometer is coupled online to a Kiel Carbonate Device (Type IV) for automated $\mathrm{CO}_{2}$ preparation. Samples were individually treated by addition of $103 \%$ phosphoric acid. The results were corrected using the NBS19 standard and are reported on the Peedee belemnite (PDB) scale. The analytical uncertainty $(2 \sigma)$ was less than $0.07 \%$.

The age model for the MD03-2707 record was developed by aligning the planktonic foraminiferal $\delta^{18} \mathrm{O}$ record of MD03-2707 (Weldeab, 2012) to the $\delta^{18} \mathrm{O}$ record of the GISP2 ice core (Blunier and Brook, 2001) (Figs. 3 and 4). The MD03-2707 $\delta^{18} \mathrm{O}$ record is dominated by changes in the amount and isotope composition of runoff from rivers that drain large part of West African monsoon area (Weldeab, 2012). In the ${ }^{14} \mathrm{C}$-dated section of the record $(<25000 \mathrm{yr}$ BP) (Weldeab et al., 2007a, b), the MD03-2707 $\delta^{18} \mathrm{O}$ time series indicates that changes in West African monsoon precipitation are synchronous within the model uncertainty with air temperature variations over Greenland, as reflected in the $\delta^{18} \mathrm{O}$ record of the GISP2 ice core (Blunier and Brook, 2001). Based on the tight correlation between changes in West African monsoon precipitation and the Greenland climate during the last $25 \mathrm{kyr} \mathrm{BP}$ and the assumption that this linkage holds throughout the millennialscale last glacial climate instabilities, I used the GISP $2 \delta^{18} \mathrm{O}$ record to establish a centennial-scale age model for the
MD03-2707 sediment sequence (Fig. 4). Uncertainties in the age model arise when the climate transitions were gradual rather than abrupt or when the West African monsoon response to Greenland climate changes was relatively weak, for instance between 25 and $32 \mathrm{kyr} \mathrm{BP}$ (Fig. 4).

\section{Results}

\section{1 $\mathrm{Mg} / \mathrm{Ca}$ and $\delta^{18} \mathrm{O}$ in G. ruber pink from Gulf of Guinea core top samples}

I analyzed $\mathrm{Mg} / \mathrm{Ca}$ and $\delta^{18} \mathrm{O}$ in tests of $G$. ruber pink from Gulf of Guinea core top samples to assess the quantitative relationship between $\mathrm{Mg} / \mathrm{Ca}$, SST, and SSS (Fig. 2). G. ruber pink is ideal for this study because this species tolerates low salinity (Ufkes et al., 1998) and lives in the upper $25 \mathrm{~m}$ of the water column (Hemleben et al., 1989). Therefore, the calcification temperature of $G$. ruber pink is assumed to reflect SST over sampling sites. On whether the $\delta^{18} \mathrm{O}$-based calcification temperature estimates (Anand et al., 2003; Elderfield and Ganssen, 2000) can be used to establish a quantitative relationship between $\mathrm{Mg} / \mathrm{Ca}$ and calcification temperature of G. ruber pink from Gulf of Guinea core top samples, calcification temperatures of $G$. ruber were calculated using the $\delta^{18} \mathrm{O}_{\text {G.ruber }}$ measurements, a modeled $\delta^{18} \mathrm{O}_{\text {seawater }}$ salinity relationship $\left(\delta^{18} \mathrm{O}_{\text {seawater }}=0.15 \times\right.$ salinity -4.61$)$ in the tropical Atlantic sea surface water (LeGrande and Schmidt, 2006), the $\delta^{18} \mathrm{O}_{\text {seawater }}-\delta^{18} \mathrm{O}_{\text {calcite-temperature }}$ equation developed by Bemis et al. $(1998)\left(T\left[{ }^{\circ} \mathrm{C}\right]=16.5-\right.$ $\left.4.81 \times\left(\delta^{18} \mathrm{O}_{\text {calcite }}-\left(\delta^{18} \mathrm{O}_{\text {seawater }}-0.27\right)\right)\right)$, and climatological SSS data over the core top collecting sites (Antonov et al., 2010). The estimated calcification temperatures vary over a range of $6^{\circ} \mathrm{C}\left(24.9{ }^{\circ} \mathrm{C}\right.$ to $\left.30.9^{\circ} \mathrm{C}\right)$. For comparison, the largest spatial and seasonal SST contrast within the Gulf of Guinea is $3.1{ }^{\circ} \mathrm{C}$. Furthermore, the upper range of the estimated calcification temperature exceeded the warmest annual mean WOA09 SST by $2.9^{\circ} \mathrm{C}$ (Fig. S1). I conclude that

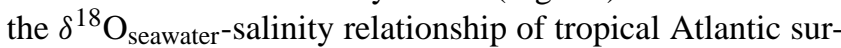
face water does not adequately represent that of the Gulf of Guinea from which there is no measurement of $\delta^{18} \mathrm{O}_{\text {seawater }}$ available. Instead, I used annual and seasonal WOA09 data to explore the $\mathrm{Mg} / \mathrm{Ca}-\mathrm{SST}-\mathrm{SSS}$ relationship.

Core top $\mathrm{Mg} / \mathrm{Ca}$ ratios vary between 3.02 and $4.81 \mathrm{mmol} \mathrm{mol}^{-1}$. Multivariate analysis of the core top $\mathrm{Mg} / \mathrm{Ca}, \Delta \mathrm{CO}_{3}^{2-}$, SSS, and SST indicates that temperature exerts the greatest control over $\mathrm{Mg}$ uptake in $G$. ruber pink, as expressed in the following equation: $\mathrm{Mg} / \mathrm{Ca}\left[\mathrm{mmol} \mathrm{mol}{ }^{-1}\right]$ $=0.31 \times \exp (0.080 \quad \pm 0.02) \quad \times T\left[{ }^{\circ} \mathrm{C}\right] \quad+(0.01 \pm 0.009)$ $\times$ SSS[psu]. A unit change in SST and SSS is reflected by $8 \pm 2 \%$ and $1 \pm 0.9 \%$ changes in foraminiferal $\mathrm{Mg} / \mathrm{Ca}$, respectively. Multivariate analysis identifies no correlation between $\Delta \mathrm{CO}_{3}^{2-}$ and core top $\mathrm{Mg} / \mathrm{Ca}$, indicating that preferential $\mathrm{Mg}$ dissolution is unlikely. With an $r^{2}$ of 0.22 , the significance of this $\mathrm{Mg} / \mathrm{Ca}-\mathrm{SST}-\mathrm{SSS}$ correlation is, however, 


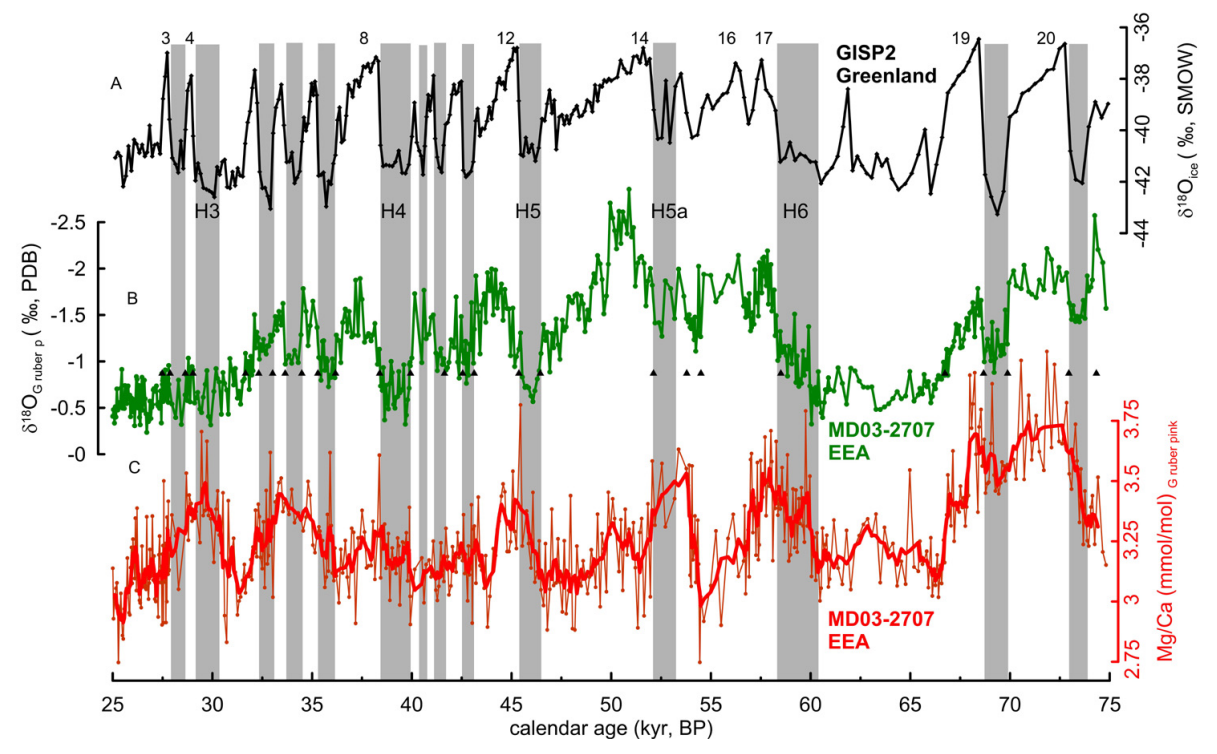

Fig. 4. (a) GISP2 $\delta^{18} \mathrm{O}_{\text {ice }}$ record compared with the $\delta^{18} \mathrm{O}$ (Weldeab, 2012) (b) and $\mathrm{Mg} / \mathrm{Ca}$ records (c) analyzed in $G$. ruber (pink). (c) Thin and bold red lines present individual $\mathrm{Mg} / \mathrm{Ca}$ measurements and a 5-point running average, respectively. Triangles mark tie points used to align $\delta^{18} \mathrm{O}$ shifts in the MD03-2707 record (b) with the GISP2 $\delta^{18} \mathrm{O}_{\text {ice }}$ record (a). Vertical gray bars indicate stadials and Heinrich events. Numbers indicate interstadials.

weak. The relatively weak correlation can be attributed to the following constraints. Firstly, the spatial resolution of core top sampling across the SST and SSS gradients in the Gulf of Guinea (Fig. 2a-b) is much higher than that of SST and SSS in the WOA09 data set $\left(0.5^{\circ} \times 0.5^{\circ}\right)$ (Antonov et al., 2010; Locarnini et al., 2010), possibly preventing precise assignment of SST and SSS to individual $\mathrm{Mg} / \mathrm{Ca}$ measurements. Secondly, while approximately $90 \%$ of the core top samples were recovered from sites of high sedimentation rates, a few core top samples from greater water depths may be older than the modern due to a relatively low sedimentation rate, a problem that is inherent to all core top studies. Thirdly and most importantly, the seasonal as well as spatial SST variation of $3.1^{\circ} \mathrm{C}$ is too small for a robust $\mathrm{Mg} / \mathrm{Ca}$-temperature calibration. Nonetheless, the multivariate analysis demonstrates that change in temperature is the most dominant environmental factor that determines changes in $\mathrm{Mg} / \mathrm{Ca}$ of foraminiferal calcite.

Comparison of the core top $\mathrm{Mg} / \mathrm{Ca}$ data with annual and seasonal SSTs shows that summer SST with a spatial variation between $27.3^{\circ} \mathrm{C}$ and $24.2^{\circ} \mathrm{C}$ over the core top sampling sites better matches the spatial variability of the $\mathrm{Mg} / \mathrm{Ca}$ data (Figs. 2c and S2). Furthermore, $\mathrm{Mg} / \mathrm{Ca}$ plotted against summer SST falls within the global calibration curve and its area of uncertainty (Anand et al., 2003; Dekens et al., 2002) (Figs. 2c and S2). A main seasonal feature that most likely explains the better match between the core top $\mathrm{Mg} / \mathrm{Ca}$ data and mean summer SST is the significantly enhanced nutrient availability during the summer (Grodsky et al., 2008; Jouanno et al., 2011a, b; Okumura and Xie, 2006). According to Jouanno et al. (2011a), a strengthening of the Guinea Cur- rent causes velocity shear and, as a consequence, shoaling of the thermocline and nutricline to depths of $10-40 \mathrm{~m}$. Therefore, along the east-west trending coast from which most of the samples were retrieved (Fig. 2), the concentration of chlorophyll- $a$ is very high between July and September (see Fig. 6 in Jouanno et al., 2011a). Outside the runoff-influenced area (Fig. 2), the seasonally pronounced contrast in nutrient availability most likely skews planktonic foraminiferal production toward the summer season.

Culture experiments suggest that changes in planktonic foraminiferal $\mathrm{Mg} / \mathrm{Ca}$ of $2.3 \%$ (Dueñas-Bohorquez et al., 2009), $4 \pm 3 \%$ (Lea et al., 1999), $5 \pm 3 \%$ (Kisakürek et al., 2008), or $\sim 7 \%$ (Nürnberg et al., 1996) correspond to a change in salinity of one unit. In contrast, some $\mathrm{Mg} / \mathrm{Ca}$ data analyzed in core top samples from tropical and subtropical oceans show significantly higher values that are attributed to the effect of high salinity (Arbuszewski et al., 2010; Ferguson et al., 2008; Mathien-Blard and Bassinot, 2009). Arbuszewski et al. (2010) pointed out that only salinity levels above 35 psu significantly affect foraminiferal $\mathrm{Mg} / \mathrm{Ca}$. Several studies provide equations to quantify the magnitude of $\mathrm{Mg} / \mathrm{Ca}$ changes in G. ruber that may potentially be attributed to the salinity effect (Arbuszewski et al., 2010; Kisakürek et al., 2008; Mathien-Blard and Bassinot, 2009). Applying these equations to the summer SSTs, summer SSSs, and carbonate ion concentrations over the core top sampling sites, I calculated the predicted $\mathrm{Mg} / \mathrm{Ca}$ and compared these values with the analyzed core top $\mathrm{Mg} / \mathrm{Ca}$ data (Fig. 2d). The predicted $\mathrm{Mg} / \mathrm{Ca}$ values obtained using the equations proposed by Arbuszewski et al. (2010) and Mathien-Blard and Bassinot (2009) deviate from the 


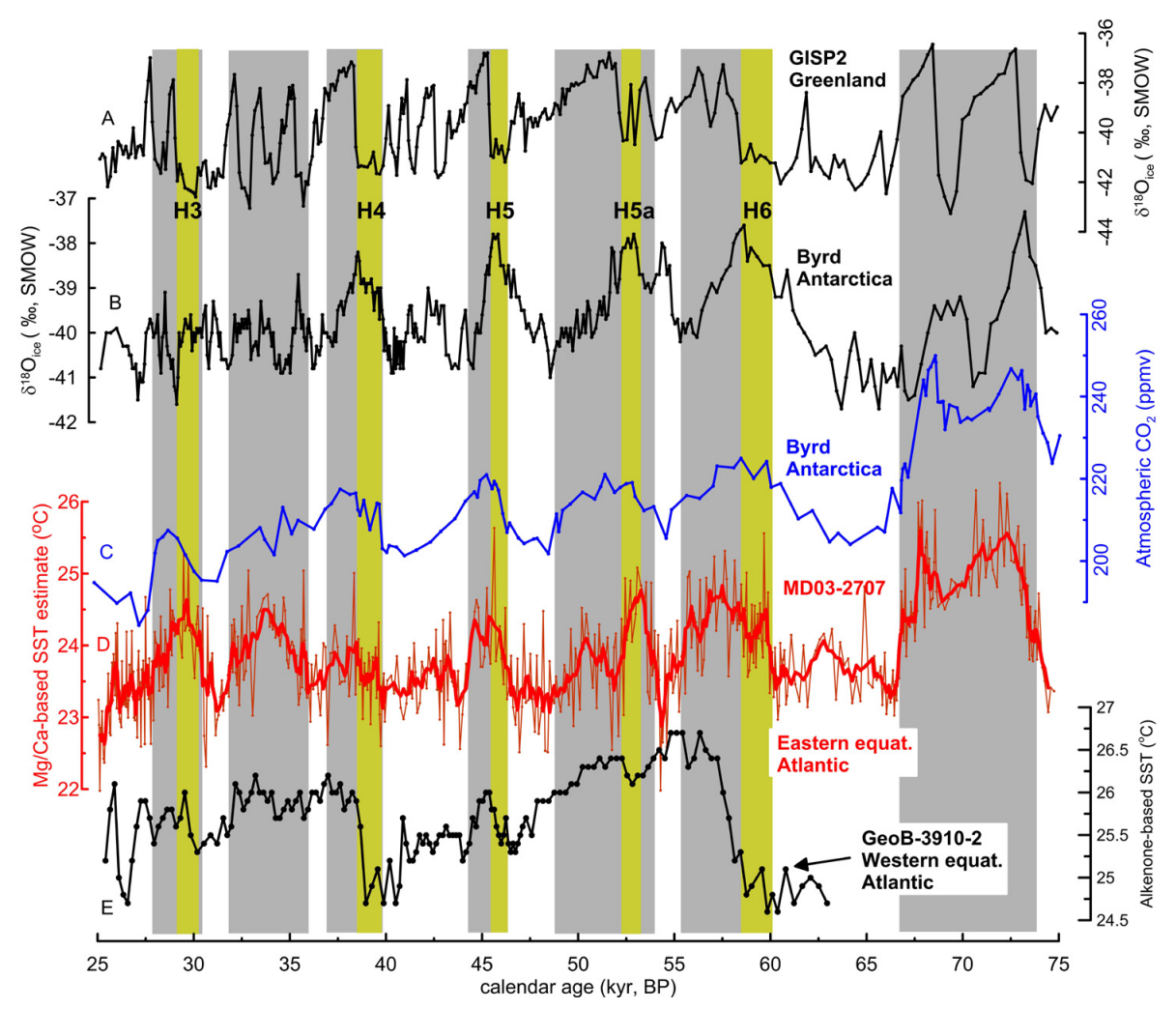

Fig. 5. (a) Greenland and (b) Antarctica ice core $\delta^{18} \mathrm{O}$ records (Blunier and Brook, 2001) compared with (c) atmospheric $\mathrm{CO}_{2}(\mathrm{Ahn}$ and Brook, 2008) and (d) eastern equatorial Atlantic SST estimates (red bold line: 5-point running average). (e) Shown are also alkenone-based SST estimates from western equatorial Atlantic (Jaeschke et al., 2007). Gray and yellow (period of Heinrich events) bars indicate EEA warm episodes.

analyzed values by up to $2.05 \mathrm{mmol} \mathrm{mol}^{-1}$ (Fig. 2d). The difference between predicted and analyzed $\mathrm{Mg} / \mathrm{Ca}$ was much larger than $2.05 \mathrm{mmol} \mathrm{mol}^{-1}$ when annual and winter SSS were applied (Fig. S2). Overall, the above equations are inadequate for describing the Gulf of Guinea core top data. The equation developed by Kisakürek et al. (2008) yielded a relatively narrow range $\left(1.7 \mathrm{mmol} \mathrm{mol}^{-1}\right)$. Similarly, the global equation with no correction for salinity (Anand et al., 2003; Dekens et al., 2002) yields predicted $\mathrm{Mg} / \mathrm{Ca}$ values that are relatively close to the measured values with a range of $1.7 \mathrm{mmol} \mathrm{mol}^{-1}$. In the salinity range between 32.75 and 34.3 psu (Fig. 2d), the expected $\mathrm{Mg} / \mathrm{Ca}$ is much closer to the analyzed values, indicating the global calibration equation is most suitable for converting the MD03-2707 Mg/Ca time series into SST estimates.

\subsection{Thermal variation of EEA SST during the last glacial}

I combined the 320 new measurements with $222 \mathrm{Mg} / \mathrm{Ca}$ measurements from a previous study (Weldeab et al., 2007a). The new sampling significantly enhanced the temporal resolution and exposes centennial- and millennial-scale climate vari- ability that was not recognized in the relatively low-resolved overview study (Weldeab et al., 2007a).

Throughout the investigated interval, $\mathrm{Mg} / \mathrm{Ca}$ varies between 2.75 and $4.02 \mathrm{mmol} \mathrm{mol}^{-1}$ (Fig. 4c). The multidecadally resolved $\mathrm{Mg} / \mathrm{Ca}$ record exhibits high frequency oscillations most likely due to seasonal, annual, and decadal imprints as well as to bioturbation (Fig. 4c). The focus of the discussion is on centennial-scale variation, as highlighted by a 5-point running average. I tested the applicability of the $\mathrm{Mg} / \mathrm{Ca}$-SST-SSS equations experimentally developed by Kisakürek et al. (2008) as well as the one derived from the Gulf of Guinea core top data, and compared the results with those obtained using the global $\mathrm{Mg} / \mathrm{Ca}-$ SST calibration equation (Anand et al., 2003; Dekens et al., 2002). Foraminiferal Ba/Ca-based runoff-induced SSS estimates were used (Weldeab, 2012) to consider the salinity effect, noting that uncertainty in the salinity estimate may affect the reconstructed SST time series. Time series of SST estimates obtained using equations that include correction for salinity effects reveals glacial SSTs exceeding modern annual and summer SSTs by several ${ }^{\circ} \mathrm{C}$ (Fig. S3). It is obvious that the anomalously high SST estimates reflect a largescale overestimation of the salinity effect. Due to the inadequacy of existing equations for salinity correction and, more 


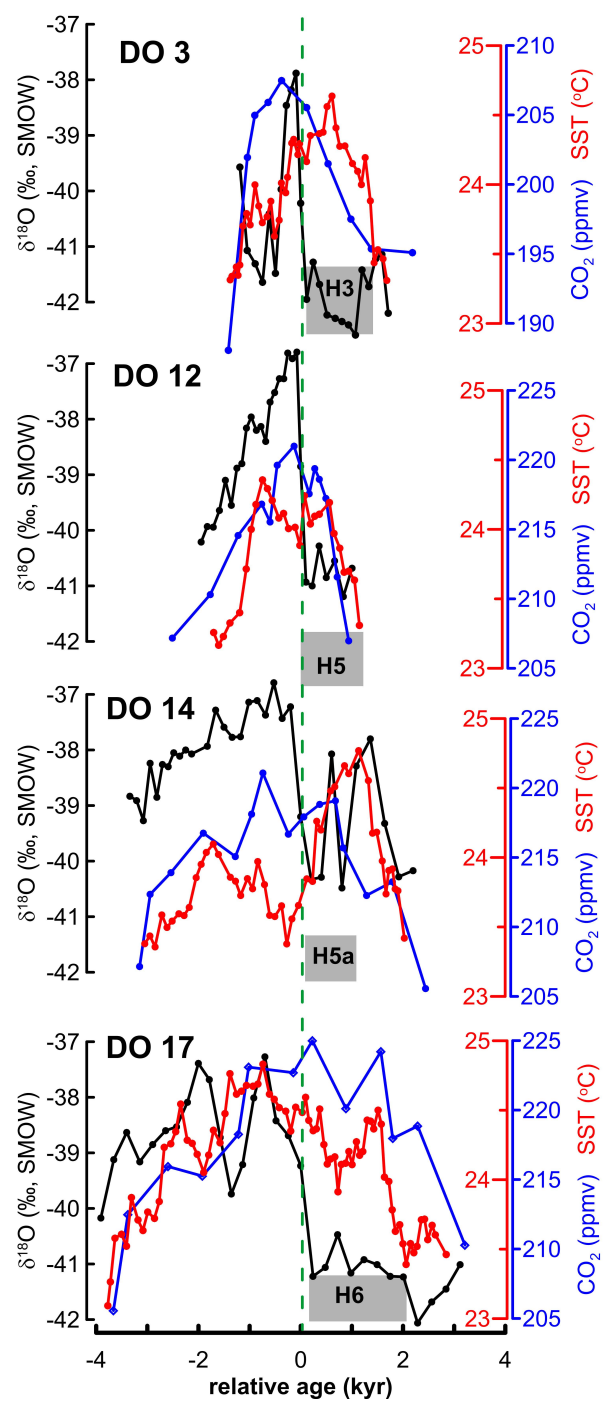

Fig. 6. 5-point running average of the EEA SST record (red) plotted relative to the timing of rapid air temperature warming over Greenland (green dashed line) during DO events, as indicated by the GISP2 record (Blunier and Brook, 2001) (black line), and atmospheric $\mathrm{CO}_{2}$ changes (blue) (Ahn and Brook, 2008). Gray bars indicate period of Heinrich events.

importantly, the fact that Gulf of Guinea core top data are well described by the global calibration curve (Fig. 2c and d), the latter has been applied to convert the $\mathrm{Mg} / \mathrm{Ca}$ time series into SST estimates.

The $\mathrm{Mg} / \mathrm{Ca}$-based SST estimates reveal numerous millennial-scale (2-4.5 kyr) oscillations whose magnitude varied between 0.8 and $2{ }^{\circ} \mathrm{C}$. Prominent episodes of temperature rise include time intervals between $74.6 \pm 0.4$ and $72.7 \pm 0.4 \mathrm{kyr}$ BP with SST increases from $23.4 \pm 0.2^{\circ} \mathrm{C}$ to $25.5 \pm 0.5^{\circ} \mathrm{C}$ and between $54.4 \pm 0.1$ and $53.3 \pm 0.2 \mathrm{kyr}$ BP with SST changes from $22.9 \pm 0.6^{\circ} \mathrm{C}$ to $24.8 \pm 0.1^{\circ} \mathrm{C}$. Similarly, SST changes from $23.2 \pm 0.3^{\circ} \mathrm{C}$ to $24.4 \pm 0.7^{\circ} \mathrm{C}$ between $46.8 \pm 0.3$ and $45.5 \pm 0.2 \mathrm{kyr} \mathrm{BP}$ and from
$23.1 \pm 0.2^{\circ} \mathrm{C}$ to $24.2 \pm 0.3{ }^{\circ} \mathrm{C}$ between $31.3 \pm 0.4$ and $29.4 \pm 0.4 \mathrm{kyr}$ BP (Figs. 5 and 6) are evident. Prior to $60 \mathrm{kyr}$ $\mathrm{BP} \mathrm{Mg} / \mathrm{Ca}$ increases were correlated with negative swings in the $\delta^{18} \mathrm{O}$ record. After $60 \mathrm{kyr}$, the onset of centennialscale increases in $\mathrm{Mg} / \mathrm{Ca}$ was generally accompanied by an increase in $\delta^{18} \mathrm{O}$.

\section{Discussion}

Comparison of the Gulf of Guinea SST time series with both Greenland and Antarctic ice core records (Ahn and Brook, 2008; Blunier and Brook, 2001) indicates that the timing of abrupt EEA SST rises was synchronous within the age model uncertainty with the onsets of Heinrich events and rapid drops in air temperature over Greenland (Figs. 5 and 6) (Blunier and Brook, 2001; Heinrich, 1988; Rashid et al., 2003; Vidal et al., 1997). Furthermore, Gulf of Guinea SST rises were paralleled by a rise in atmospheric $\mathrm{CO}_{2}$ concentration ranging from 12 to $20 \mathrm{ppmv}$ (Ahn and Brook, 2008). A doubling of pre-industrial atmospheric $\mathrm{CO}_{2}$ concentration is estimated to increase the global mean near-surface air temperature by $2-4.5^{\circ} \mathrm{C}$ (Knutti and Hegerl, 2008; Lea, 2004; Roe and Baker, 2007; Schmittner et al., 2011). Based on the above climate sensitivity estimate, the contribution of atmospheric $\mathrm{CO}_{2}$ rise between 12 and 20 ppmv to EEA surface water warming between 0.8 and $2.0^{\circ} \mathrm{C}$ is low, varying between 0.1 and $0.3{ }^{\circ} \mathrm{C}$. I caution, however, that the application of the above climate sensitivity estimate to episodes with different climate boundary conditions is likely to yield less accurate estimates. A more likely cause for the relatively synchronous co-variation of EEA SST and atmospheric $\mathrm{CO}_{2}$ (Fig. 6) is that both the equatorial Atlantic and deep ocean carbon reservoir (Anderson et al., 2009; Toggweiler and Lea, 2011) responded very sensitively to rapid reorganization of atmospheric and oceanic circulation.

Rapid EEA SST rise concomitant with the onset of Heinrich events is consistent with the results of modeling studies that predict warming of the tropical Atlantic in response to melt-water influx into the North Atlantic and the ensuing reduction of northward heat transport (Chang et al., 2008; Chiang et al., 2008; Knutti et al., 2004; Krebs and Timmermann, 2007; Lee et al., 2011; Liu et al., 2009; Lohmann, 2003). However, this study shows that, with the exception of H5a, the termination of the EEA warm episodes lags the timing of rapid temperature rises over Greenland by $\sim 2.2 \mathrm{kyr}, \sim$ $2.3 \mathrm{kyr}, \sim 1.3 \mathrm{kyr}$, and $\sim 1.2 \mathrm{kyr}$ during DO events $3,12,17$, and 18, respectively (Fig. 6). The significant lag of EEA SST decline relative to the timing of rapid warming in the northern high latitudes is at variance with the notion that the end of each Heinrich event was accompanied by a sudden release of heat that had accumulated in the tropical Atlantic Ocean (Knutti et al., 2004; Liu et al., 2009). In order to explore possible zonal differences within the equatorial Atlantic, I compared the record from EEA with alkenone-derived SST 
estimates (Jaeschke et al., 2007) from the western tropical Atlantic, representing the main route of meridional heat and surface water mass exchange (Ganachaud and Wunsch, 2000). I note that comparison of $\mathrm{Mg} / \mathrm{Ca}$ - and alkenonederived SST records can result in uncertainties due to possible differences in the seasonality and habitat depth of $G$. ruber pink and coccolithophorids. However, the deglacial $\mathrm{Mg} / \mathrm{Ca}-\mathrm{SST}$ record (Weldeab et al., 2006) from a site very close to that of Jaeschke et al. (2007) shows the same trend as revealed in the alkenone-based SST record (Jaeschke et al., 2007), suggesting that the latter reflects a proxy-independent thermal state of the western equatorial Atlantic. In strong contrast to the EEA SST record, the western equatorial Atlantic time series exhibits rapid SST declines and rises that are synchronous with the onset and termination of Heinrich events (Jaeschke et al., 2007) (Fig. 5), respectively. Farther to the north in the Caribbean Sea, SST reconstruction indicates surface warmth during the onset of Heinrich events (Hüls and Zahn, 2000). The feature that emerges from the comparison is a spatially and temporally heterogeneous pattern of tropical Atlantic thermal response to the millennial-scale high latitude climate oscillations (Fig. 5). I suggest that the thermal heterogeneity of the equatorial Atlantic may be related to changes in wind fields that at a regional level could have reinforced and counteracted a possible basin-wide surface warming due to reduced northward heat transport (Chang et al., 2008; Chiang et al., 2003, 2008; Krebs and Timmermann, 2007; Lee et al., 2011; Lohmann, 2003). In the Gulf of Guinea, a weakening of the Guinea Current could have contributed to the EEA surface water warming. In the modern climate, a southward displacement of the intertropical convergence zone (ITCZ) and a weak summer monsoon are accompanied by weakening of the Guinea Current, leading to surface water warming in the Gulf of Guinea (Philander, 1986; Schott et al., 2002). However, the abrupt strengthening of the West African monsoon at the end of Heinrich events, as indicated by the $\delta^{18} \mathrm{O}$ record (Fig. 4) (Weldeab, 2012), is not paralleled by an equally rapid decline in SST. The decoupling of EEA SST and West African monsoon changes suggests a less prominent role of the Guinea Current.

Changes in wind fields and surface currents across the equatorial Atlantic may provide a viable explanation for the observed zonal SST patterns (Fig. 2). Proxy records from the Brazilian continental margin $\left(\sim 5^{\circ} \mathrm{S}\right)$ (Arz et al., 1998; Jennerjahn et al., 2004) and from northeastern Brazil $\left(\sim 10^{\circ} \mathrm{S}\right)$ (Wang et al., 2004) indicate wet conditions during Heinrich events that are interpreted to reflect a large-scale southward displacement of the mean position of the ITCZ. In contrast, the West African monsoon was severely weakened (Weldeab, 2012), but the average seasonal position of the ITCZ most likely remained north of the Gulf of Guinea coast $\left(\sim 6-4^{\circ} \mathrm{N}\right)$ as no SST drops are observed during Heinrich events that would have otherwise occurred due to trade wind-induced upwelling. If this inference is correct, then a highly asymmetric shift of the ITCZ existed over the Gulf of Guinea and the western equatorial Atlantic (WEA). Instrumental data covering periods of large-scale southward shift of the ITCZ over the WEA reveal that the associated southward shift of the SE trade winds weakens the North Brazil Current (NBC) and promotes the development of a westerly current of warm surface water that causes a rapid heat buildup in the EEA (Philander, 1986; Schott et al., 2002). Similarly, freshwater experiments simulating Heinrich event-like conditions (Knutti et al., 2004; Lohmann, 2003) suggest that the development of a westerly equatorial surface current and a warmer EEA relative to the WEA is a robust feature of model outcomes, providing a potentially viable explanation for the proxy-based observation of thermal asymmetry across the equatorial Atlantic. The difference in the timing and pace of SST changes in the western (Jaeschke et al., 2007) and eastern equatorial Atlantic (this study) immediately after the suspension of fresh water flux into the North Atlantic represents a marked zonal feature. Following the cessation of meltwater flux into the North Atlantic, a rapid resumption of vigorous AMOC (Knutti et al., 2004; Liu et al., 2009) and a northward shift of southeasterly winds (Lohmann, 2003) could have strengthened the NBC and weakened the eastward surface current and the Equatorial Undercurrent (EUC) that, under modern conditions, forms as a retroflection of the NBC (Fig. 1). Though somewhat speculative, a gradual weakening of the easterly surface current may explain the gradual EEA SST decline, respectively. Alternatively, the persistence of elevated SST in the EEA may be related to regional processes, possibly involving the variability of the Guinea Current. Regardless of the detail of the responsible mechanisms, the record indicates that the surface water of the eastern equatorial Atlantic responded very sensitively to millennial-scale climate perturbation during the last glacial episode. The zonal SST gradient and temporal heterogeneity within the equatorial Atlantic demands, however, considerable thermal modulation by regional wind-driven surface currents.

\section{Conclusions}

$\mathrm{Mg} / \mathrm{Ca}$ analysis on G. ruber (variety pink) tests selected from 59 Gulf of Guinea core top samples indicates that $\mathrm{Mg} / \mathrm{Ca}$ data reflect mean summer SST. This is likely due to currentinduced shoaling of the summer nutricline along the eastwest trending coastal waters (Jouanno et al., 2011a) where most of the samples were collected. A multivariate analysis indicates that one unit of SST and SSS changes correspond to $8 \pm 2 \%$ and $1 \pm 0.9 \%$ changes in $\mathrm{Mg} / \mathrm{Ca}$, respectively. This study shows also that the available equations employing salinity correction (Arbuszewski et al., 2010; Kisakürek et al., 2008; Mathien-Blard and Bassinot, 2009) are inadequate for analyzing the Gulf of Guinea data because they significantly under- or over-estimate $\mathrm{Mg} / \mathrm{Ca}$ values. The Gulf of Guinea core top data show that the global calibration (Anand 
et al., 2003; Dekens et al., 2002) reliably describes the relationship between $\mathrm{Mg} / \mathrm{Ca}$ in $\mathrm{G}$. ruber and the SST of the equatorial Atlantic.

This study established for the first time a centennially resolved and continuous temperature record of EEA corresponding to times of rapid climate oscillations. The EEA SST record provides evidence that the equatorial Atlantic was highly sensitive to millennial-scale episodes of ice sheet and atmospheric instability and responded very differently than the upwelling-dominated low latitude continental margins (Jaeschke et al., 2007; Lea et al., 2003; Zhao et al., 1995). EEA SST rose between $0.8^{\circ} \mathrm{C}$ and $2{ }^{\circ} \mathrm{C}$ concomitant with the timing of meltwater flux into the North Atlantic. Reduced heat export from the tropical Atlantic to the northern high latitudes, as suggested by modeling studies, may provide a partial explanation for the EEA surface water warmth. The persistence of elevated SST following the abrupt termination of the Heinrich events and the spatial heterogeneity of the direction, magnitude, and duration of thermal changes across the equatorial Atlantic demand, however, considerable modulation of the equatorial Atlantic SST by regional processes. I hypothesize that changes in wind-induced low latitude zonal surface currents significantly contributed to the heterogeneous patterns of equatorial Atlantic SST. While a broad and dense spatial coverage of highly resolved tropical Atlantic SST records is required to reach a conclusive assessment, the findings of this study suggest a limited contribution of the equatorial Atlantic to the rapid temperature rise in northern high latitudes following the termination of Heinrich events.

\section{Supplementary material related to this article is available online at: http://www.clim-past.net/8/1705/ 2012/cp-8-1705-2012-supplement.pdf.}

Acknowledgements. I thank Dorothy K. Pak and David W. Lea for discussion, suggestion, and comments. I thank G. Paradis for ICP-MS operation, James P. Kennett, Alexander R. Simms, and Gerrit Lohmann for discussion, Wolfgang Kuhnt for providing core top samples. I also thank the three reviewers for their insightful and constructive comments and Patrizia Ziveri for her editorial handling and comments. A generous start-up package and UCSB career development award is greatly acknowledged.

Edited by: P. Ziveri

\section{References}

Ahn, J. and Brook, E. J.: Atmospheric $\mathrm{CO}_{2}$ and Climate on Millennial Time Scales During the Last Glacial Period, Science, 322, 83-85, 10.1126/science.1160832, 2008.

Anand, P., Elderfield, H., and Conte, M. H.: Calibration of $\mathrm{Mg} / \mathrm{Ca}$ thermometry in planktonic foraminifera from a sediment trap time series, Paleoceanography, 18, 1050, doi:10.1029/2002PA000846, 2003.

Anderson, R. F., Ali, S., Bradtmiller, L. I., Nielsen, S. H. H., Fleisher, M. Q., Anderson, B. E., and Burckle, L. H.: WindDriven Upwelling in the Southern Ocean and the Deglacial Rise in Atmospheric $\mathrm{CO}_{2}$, Science, 323, 1443-1448, 2009.

Antonov, J. I., D. Seidov, Boyer, T. P., Locarnini, R. A., Mishonov, A. V., Garcia, H. E., Baranova, O. K., Zweng, M. M., and Johnson, D. R.: World Ocean Atlas 2009, Volume 2: Salinity, in: NOAA Atlas NESDIS 69, edited by: Levitus, S., US Government Printing Office, Washington, D.C., 184 pp., 2010.

Arbuszewski, J., deMenocal, P., Kaplan, A., and Farmer, E. C.: On the fidelity of shell-derived [delta] ${ }^{18}$ Oseawater estimates, Earth Planet. Sci. Lett., 300, 185-196, 2010.

Arz, H. W., Pätzold, J., and Wefer, G.: Correlated millennialscale changes in surface hydrography and terrigenous sediment yield infered from Last-Glacial marine deposits off northeastern Brazil, Quaternary Res., 50, 157-166, 1998.

Bard, E., Rostek, F., Turon, J.-L., and Gendreau, S.: Hydrological impact of Heinrich events in the subtropical Northeast Atlantic, Science, 289, 1321-1323, 2000.

Barker, S., Greaves, M., and Elderfield, H.: A study of cleaning procedures used for $\mathrm{Mg} / \mathrm{Ca}$ paleothermometry, Geochem. Geophy. Geosy., 4, 8407, doi:10.1029/2003GC000559, 2003.

Barker, S., Diz, P., Vautravers, M. J., Pike, J., Knorr, G., Hall, I. R., and Broecker, W. S.: Interhemispheric Atlantic seesaw response during the last deglaciation, Nature, 457, 1097-U1050, doi:10.1038/nature07770, 2009.

Bemis, B. E., Spero, H., Bijma, J., and Lea, D. W.: Reevaluation of oxygen isotope composition of planktonic foraminifera: experimental results and revised paleotemperature equations, Paleoceanography, 13, 150-160, 1998.

Blunier, T. and Brook, E. J.: Timing of millennial-scale climate change in Antarctica and Greenland during the last glacial period, Science, 291, 109-112, 2001.

Bond, G., Showers, W., Cheseby, M., Lotti, R., Almasi, P., deMenocal, P., Priore, P., Cullen, H., Hajdas, I., and Bonani, G.: A pervasive millennial-scale cycle in North Atlantic Holocene and glacial climates, Science, 278, 1257-1266, 1997.

Cacho, I., Grimalt, J. O., Pelejero, C., Canals, M., Sierro, F. J., Flores, J. A., and Shackleon, N.: Dansgaard-Oeschger and Heinrich event imprints in Alboran Sea paleotemperatures, Paleoceangraphy, 14, 698-705, 1999.

Chang, P., Zhang, R., Hazeleger, W., Wen, C., Wan, X., Ji, L., Haarsma, R. J., Breugem, W.-P., and Seidel, H.: Oceanic link between abrupt changes in the North Atlantic Ocean and the African monsoon, Nat. Geosci., 1, 444-448, 2008.

Chiang, J. C. H., Biasutti, M., and Battisti, D. S.: Sensitivity of the Atlantic Intertropical Convergence Zone to Last Glacial Maximum boundary conditions, Paleoceanography, 18, 1094, doi:10.1029/2003pa000916, 2003.

Chiang, J. C. H., Cheng, W., and Bitz, C. M.: Fast teleconnections to the tropical Atlantic sector from Atlantic thermohaline adjustment, Geophys. Res. Lett., 35, L07708, doi:10.1029/2008g1033292, 2008.

Clark, P. U., Shakun, J. D., Baker, P. A., Bartlein, P. J., Brewer, S., Brook, E., Carlson, A. E., Cheng, H., Kaufman, D. S., Liu, Z., Marchitto, T. M., Mix, A. C., Morrill, C., Otto-Bliesner, B. L., Pahnke, K., Russell, J. M., Whitlock, C., Adkins, J. F., Blois, J. 
L., Clark, J., Colman, S. M., Curry, W. B., Flower, B. P., He, F., Johnson, T. C., Lynch-Stieglitz, J., Markgraf, V., McManus, J., Mitrovica, J. X., Moreno, P. I., and Williams, J. W.: Global climate evolution during the last deglaciation, Proc. Natl. Acad. Sci., 109, E1134-E1142, doi:10.1073/pnas.1116619109, 2012.

Dansgaard, W., Johnsen, S. J., Clausen, H. B., Dahl-Hvidberg, C. S., Steffensen, J. P., Sveinbjörnsdottir, A. E., Jouzel, J., and Bond, G.: Evidence for general instability of past climate from a 250kyr ice-core record, Nature, 364, 218-220, 1993.

Dekens, P. S., Lea, D. W., Pak, D. K., and Spero, H. J.: Core top calibration of $\mathrm{Mg} / \mathrm{Ca}$ in tropical foraminifera: refining paleotemperature estimation, Geochem. Geophy. Geosy., 3, 200, doi:10.1029/2001GC000200, 2002.

Dueñas-Bohorquez, A., da Rocha, R. E., Kuroyanagi, A., Bijma, J., and Reichart, G. J.: Effect of salinity and seawater calcite saturation state on $\mathrm{Mg}$ and $\mathrm{Sr}$ incorporation in cultured planktonic foraminifera, Mar. Micropaleontol., 73, 178-189, doi:10.1016/j.marmicro.2009.09.002, 2009.

Elderfield, H. and Ganssen, G.: Past temperature and $\delta^{18} \mathrm{O}$ of surface ocean waters inferred from foraminiferal $\mathrm{Mg} / \mathrm{Ca}$ ratios, Nature, 405, 442-445, 2000.

Ferguson, J. E., Henderson, G. M., Kucera, M., and Rickaby, R. E. M.: Systematic change of foraminiferal $\mathrm{Mg} / \mathrm{Ca}$ ratios across a strong salinity gradient, Earth Planet. Sci. Lett., 265, 153-166, doi:10.1016/j.eps1.2007.10.011, 2008.

Ganachaud, A. and Wunsch, C.: Improved estimates of global ocean circulation, heat transport and mixing from hydrographic data, Nature, 408, 453-457, 2000.

Grodsky, S. A., Carton, J. A., and McClain, C. R.: Variability of upwelling and chlorophyll in the equatorial Atlantic, Geophys. Res. Lett., 35, L03610, doi:10.1029/2007g1032466, 2008.

Heinrich, H.: Origin and consequences of cyclic ice rafting in the Northeast Atlantic Ocean during the past 130,000 years, Quaternary Res., 29, 142-152, 1988.

Hemleben, C., Spindler, M., and Anderson, O. R.: Modern planktonic foraminifera, Springer-Verlag, New York, 363 pp., 1989.

Hodell, D. A., Evans, H. F., Channell, J. E. T., and Curtis, J. H.: Phase relationships of North Atlantic ice-rafted debris and surface-deep climate proxies during the last glacial period, Quaternary Sci. Rev., 29, 3875-3886, doi:10.1016/j.quascirev.2010.09.006, 2010.

Hüls, M. and Zahn, R.: Millennial-scale sea surface temperature variability in the western tropical North Atlantic from planktonic foraminiferal, Paleoceangraphy, 15, 659-678, 2000.

Jaeschke, A., Rühlemann, C., Arz, H., Heil, G., and Lohmann, G.: Coupling of millennial-scale changes in sea surface temperature and precipitation off northeastern Brazil with high-latitude climate shifts during the last glacial period, Paleoceanography, 22, PA4206, doi:10.1029/2006pa001391, 2007.

Jennerjahn, T., Ittekkot, V., Arz, H., Behling, H., Pätzold, J., and Wefer, G.: Asynchrony of preserved terrestrial and marine signals of climate change in the tropics during the Heinrich events, Science, 306, 2236-2239, 2004.

Johnsen, S. J.: Irregular glacial interstadials recorded in a new Greenland ice core, Nature, 359, 311-313, 1992.

Jouanno, J., Marin, F., du Penhoat, Y., Molines, J. M., and Sheinbaum, J.: Seasonal Modes of Surface Cooling in the Gulf of Guinea, J. Phys. Oceanogr., 41, 1408-1416, doi:10.1175/jpo-d11-031.1, 2011a.
Jouanno, J., Marin, F., du Penhoat, Y., Sheinbaum, J., and Molines, J.-M.: Seasonal heat balance in the upper $100 \mathrm{~m}$ of the equatorial Atlantic Ocean, J. Geophys. Res.-Oceans, 116, C09003, doi:10.1029/2010jc006912, 2011 b.

Kanfoush, S. L., Hodell, D. A., Charles, C. D., Guilderson, T. P., Mortyn, P. G., and Ninnemann, U. S.: Millennial-scale instability of the Antarctic Ice Sheet during the Last Glaciation, Science, 288, 1815-1818, 2000.

Key, R. M., Kozyr, A., Sabine, C. L., Lee, K., Wanninkhof, R., Bullister, J. L., Feely, R. A., Millero, F. J., Mordy, C., and Peng, T. H.: A global ocean carbon climatology: Results from Global Data Analysis Project (GLODAP), Global Biogeochem. Cy., 18, GB4031, doi:10.1029/2004gb002247, 2004.

Kisakürek, B., Eisenhauer, A., Böhm, F., Garbe-Schönberg, D., and Erez, J.: Controls on shell $\mathrm{Mg} / \mathrm{Ca}$ and $\mathrm{Sr} / \mathrm{Ca}$ in cultured planktonic foraminiferan, Globigerinoides ruber (white), Earth Planet. Sci. Lett., 273, 260-269, 2008.

Knutti, R. and Hegerl, G. C.: The equilibrium sensitivity of the Earth's temperature to radiation changes, Nat. Geosci., 1, 735743, 2008.

Knutti, R., Fluckiger, J., Stocker, T. F., and Timmermann, A.: Strong hemispheric coupling of glacial climate through freshwater discharge and ocean circulation, Nature, 430, 851-856, 2004.

Krebs, U. and Timmermann, A.: Tropical Air-Sea Interactions Accelerate the Recovery of the Atlantic Meridional Overturning Circulation after a Major Shutdown, J. Climate, 20, 4940-4956, doi:10.1175/JCLI4296.1, 2007.

Lea, D. W.: The 100 000-yr cycle in tropical SST, greenhouse forcing, and climate sensitivity, J. Climate, 17, 2170-2179, 2004.

Lea, D. W., Mashiotta, T. A., and Spero, H. J.: Controls on magnesium and strontium uptake in planktonic foraminifera determined by live culturing, Geochim. Cosmochim. Ac., 63, 2369-2379, 1999.

Lea, D. W., Pak, D. K., and Spero, H. J.: Climate impact of Late Quaternary equatorial Pacific sea temperature variations, Science, 289, 1719-1724, 2000.

Lea, D. W., Pak, D. K., Peterson, L. C., and Hughen, K. A.: Synchronity of tropical and high-latitude Atlantic temperatures over the Last Glacial termination, Science, 301, 1361-1364, 2003.

Lea, D. W., Pak, D. K., and Paradis, G.: Influence of volcanic shards on foraminiferal $\mathrm{Mg} / \mathrm{Ca}$ in a core from the Galapagos region, Geochem. Geophy. Geosy., 6, Q11P04, doi:10.1029/2005GC000970, 2005.

Lee, S.-Y., Chiang, J. C. H., Matsumoto, K., and Tokos, K. S.: Southern Ocean wind response to North Atlantic cooling and the rise in atmospheric $\mathrm{CO}_{2}$ : Modeling perspective and paleoceanographic implications, Paleoceanography, 26, PA1214, doi:10.1029/2010pa002004, 2011.

LeGrande, A. N. and Schmidt, G. A.: Global gridded data set of the oxygen isotopic composition in seawater, Geophys. Res. Lett., 33, L12604, doi:10.1029/2006GL026011, 2006.

Liu, Z., Otto-Bliesner, B. L., He, F., Brady, E. C., Tomas, R., Clark, P. U., Carlson, A. E., Lynch-Stieglitz, J., Curry, W., Brook, E., Erickson, D., Jacob, R., Kutzbach, J., and Cheng, J.: Transient Simulation of Last Deglaciation with a New Mechanism for Bolling-Allerod Warming, Science, 325, 310-314, doi:10.1126/science.1171041, 2009.

Locarnini, R. A., Mishonov, A. V., Antonov, J. I., Boyer, T. P., and Garcia, H. E.: World Volume 2: Temperature, in: NOAA Atlas 
NESDIS 69, edited by: Levitus, S., US Government Printing Office, Washington, D.C., 182 pp., 2010.

Lohmann, G.: Atmospheric and oceanic freshwater transport during weak Atlantic overturning circulation, Tellus, 55A, 438-449, 2003.

Lutze, G. F., Agwu, C. O. C., Altenbach, A., Henken-Meliies, U., Kothe, C., Muehlhan, N., Pflaumann, U., Samtleben, C., Sarnthein, M., Segl, M., Soltwedel, T., Stute, U., Tiedemann, R., and Weinholz, P.: Report of R. V. METEOR cruise M5-6 DakarLibreville 15 January-16 February 1988, 1988.

Martin, P. A. and Lea, D. W.: A simple evaluation of cleaning procedures on fossil benthic foraminiferal $\mathrm{Mg} / \mathrm{Ca}$, Geochem. Geophy. Geosy., 3, 8401, doi:10.1029/2001GC000280, 2002.

Martrat, B., Grimalt, J. O., Lopez-Martinez, C., Cacho, I., Sierro, F. J., Flores, J. A., Zahn, R., Canals, M., Curtis, J. H., and Hodell, D. A.: Abrupt Temperature Changes in the Western Mediterranean over the Past 250,000 Years, Science, 306, 1762-1765, 2004.

Mathien-Blard, E. and Bassinot, F.: Salinity bias on the foraminifera $\mathrm{Mg} / \mathrm{Ca}$ thermometry: Correction procedure and implications for past ocean hydrographic reconstructions, Geochem. Geophy. Geosy., 10, 17, Q12011, Q12011, doi:10.1029/2008gc002353, 2009.

McConnell, M. C. and Thunell, R. C.: Calibration of the planktonic foraminiferal $\mathrm{Mg} / \mathrm{Ca}$ paleothermometer: Sediment trap results from the Guaymas Basin, Gulf of California, Paleoceanography, 20, PA2016, doi:10.1029/2004pa001077, 2005.

Monnin, E., Indermuhle, A., Dallenbach, A., Fluckiger, J., Stauffer, B., Stocker, T. F., Raynaud, D., and Barnola, J.-M.: Atmospheric $\mathrm{CO}_{2}$ Concentrations over the Last Glacial Termination, Science, 291, 112-114, 2001.

NGRIP-members: High-resolution record of Northern Hemisphere climate extending into the last interglacial period, Nature, 431, 147-151, 2004.

Nürnberg, D., Bijma, J., and Hemleben, C.: Assessing the reliability of magnesium in foraminiferal calcite as a proxy for water mass temperatures, Geochim. Cosmochim. Ac., 60, 803-814, 1996.

Nürnberg, D., Ziegler, M., Karas, C., Tiedemann, R., and Schmidt, M. W.: Interacting Loop Current variability and Mississippi River discharge over the past 400 kyr, Earth Planet. Sci. Lett., 272, 278-289, 2008.

Okumura, Y. and Xie, S.-P.: Some overlooked features of tropical Atlantic climate leading to a New Niño-like phenomenon, J. Climate, 19, 5859-5874, doi:10.1175/jcli3928.1, 2006.

Patton, G. M., Martin, P. A., Voelker, A., and Salgueiro, E.: Multiproxy comparison of oceanographic temperature during Heinrich Events in the eastern subtropical Atlantic, Earth Planet. Sci. Lett., 310, 45-58, doi:10.1016/j.eps1.2011.07.028, 2011.

Philander, S. G. H.: Unsual conditions in the tropical Atlantic Ocean in 1984, Nature, 322, 236-238, 1986.

Rashid, H., Hesse, R., and Piper, D. J. W.: Evidence for an additional Heinrich event between H5 and H6 in the Labrador Sea, Paleoceanography, 18, 1077, doi:10.1029/2003pa000913, 2003.

Robbins, L. L., Hansen, M. E., Kleypas, J. A., and Meylan, S. C.: $\mathrm{CO}_{2}$ calc - A user-friendly seawater carbon calculator for Windows, Max OS X, and iOS (iPhone): US Geological Survey Open-File Report 2010-1280, 2010.

Roe, G. H. and Baker, M. B.: Why Is Climate Sensitivity So Unpredictable?, Science, 318, 629-632, doi:10.1126/science.1144735, 2007.
Rühlemann, C., Mulitza, S., Müller, P. J., Wefer, G., and Zahn, R.: Warming of the tropical Atlantic Ocean and slowdown of thermohaline circulation during the last deglaciation, Nature, 402, 511-514, 1999.

Sachs, J. P. and Anderson, R. F.: Increased productivity in the subantarctic ocean during Heinrich events, Nature, 434, 1118-1121, 2005.

Schlitzer, R.: Ocean Data View, available at: http://odv.awi.de, 2012.

Schmidt, M. W. and Lynch-Stieglitz, J.: Florida Straits deglacial temperature and salinity change: Implications for tropical hydrologic cycle variability during the Younger Dryas, Paleoceanography, 26, PA4205, doi:10.1029/2011pa002157, 2011.

Schmidt, M. W., Spero, H. J., and Lea, D. W.: Links between salinity variation in the Caribbean and North Atlantic thermohaline circulation, Nature, 428, 160-163, 2004.

Schmittner, A., Urban, N. M., Shakun, J. D., Mahowald, N. M., Clark, P. U., Bartlein, P. J., Mix, A. C., and Rosell-Melé, A.: Climate Sensitivity Estimated from Temperature Reconstructions of the Last Glacial Maximum, Science, 334, 1385-1388, doi:10.1126/science.1203513, 2011.

Schott, F. A., Brandt, P., Hamann, M., Fischer, J., and Stramma, L.: On the boundary flow off Brazil at $5-10^{\circ} \mathrm{S}$ and its connection to the interior tropical Atlantic, Geophs. Res. Lett., 29, 1840, doi:10.1029/2002GL014786, 2002.

Shackleton, N., Hall, M., and Vincent, E.: Phase relationships between millennial-scale events 64,000-24,000 years ago, Paleoceanography, V15, 565-569, 2000.

Shakun, J. D., Clark, P. U., He, F., Marcott, S. A., Mix, A. C., Liu, Z., Otto-Bliesner, B., Schmittner, A., and Bard, E.: Global warming preceded by increasing carbon dioxide concentrations during the last deglaciation, Nature, 484, 49-54, doi:10.1038/nature10915, 2012.

Siddall, M., Rohling, E. J., Almogi-Labin, A., Hemleben, C., Meischner, D., Schmelzer, I., and Smeed, D. A.: Sea-level fluctuations during the last glacial cycle, Nature, 423, 853-858, 2003.

Steinke, S., Chiu, H.-Y., Yu, P.-S., Shen, C.-C., Löwemark, L., Mii, H.-S., and Chen, M.-T.: $\mathrm{Mg} / \mathrm{Ca}$ ratios of two Globigerinoides ruber (white) morphotypes: Implications for reconstructing past tropical/subtropical surface water conditions, Geochem. Geophys. Geosyst., 6, Q11005, doi:10.1029/2005gc000926, 2005.

Stocker, T. F.: Climate change: the seesaw effect, Science, 282, 6162, 1998.

Timmermann, A., Krebs, U., Justino, F., Goosse, H., and Ivanochko, T.: Mechanisms for millennial-scale global synchronization during the last glacial period, Paleoceanography, 20, Pa4008, doi:10.1029/2004pa001090, 2005.

Toggweiler, J. R. and Lea, D. W.: Temperature differences between the hemispheres and ice age climate variability, Paleoceanography, 25, PA2212, doi:10.1029/2009pa001758, 2011.

Ufkes, E., Fred Jansen, J. H., and Brummer, G.-J. A.: Living planktonic foraminifera in the eastern South Atlantic during spring: Indicators of water masses, upwelling and the Congo (Zaire) River plume, Mar. Micropaleontol., 33, 27-53, doi:10.1016/s03778398(97)00032-7, 1998.

Vidal, L., Labeyrie, L., Cortijo, E., Arnold, M., Duplessy, J. C., Michel, E., Becque, S., and Van Weering, T. C. E.: Evidence for changes in the North Atlantic Deep Water linked to metwater surges during the Heinrich events, Earth Planet. Sci. Lett., 146, 
13-27, 1997.

Wang, L.: Isotopic signals in two morphotypes of Globigerinoides ruber (white) from the South China Sea: implications for monsoon climate change during the last glacial cycle, Palaeogeogr. Palaeocl., 161, 381-394, doi:10.1016/s0031-0182(00)00094-8, 2000.

Wang, X., Auler, A. S., Edwards, R. L., Cheng, H., Cristalli, P. S., Smart, P. L., Richards, D. A., and Shen, C.-C.: Wet periods in northern Brazil over the past $210 \mathrm{kyr}$ linked to distant climate anomalies, Nature, 432, 740-743, 2004.

Weldeab, S.: Bipolar modulation of millennial-scale West African monsoon variability during the last glacial $(75,000-$ 25,000 years ago), Quaternary Sci. Rev., 40, 21-29, doi:10.1016/j.quascirev.2012.02.014, 2012.
Weldeab, S., Schneider, R. R., and Koelling, M.: Deglacial sea surface temperature and salinity increase in the western tropical Atlantic in synchrony with high latitude climate instabilities, Earth Planet. Sci. Lett., 241, 699-706, 2006.

Weldeab, S., Lea, D. W., Schneider, R. R., and Andersen, N.: 155,000 years of West African monsoon and ocean thermal evolution, Science, 316, 1303-1307, 2007a.

Weldeab, S., Lea, D. W., Schneider, R. R., and Andersen, N.: Centennial scale climate instabilities in a wet early Holocene West African monsoon, Geophys. Res. Lett., 34, L24702, doi:10.1029/2007GL031898, 2007b.

Zhao, M., Beveridge, N. A. S., Shackleton, N. J., Sarnthein, M., and Eglinton, G.: Molecular stratigraphy of cores off northwest Africa: Sea surface temperature history over the last $80 \mathrm{kyr}, \mathrm{Pa}-$ leoceanography, 10, 661-675, 1995. 